\title{
Pleistocene separation of mitochondrial lineages of Mytilus spp. mussels from Northern and Southern Hemispheres and strong genetic differentiation among southern populations
}

\author{
Karin Gérard ${ }^{\mathrm{a}, *}$, Nicolas Bierne ${ }^{\mathrm{b}, \mathrm{c}}$, Philippe Borsa ${ }^{\mathrm{d}}$, Anne Chenuil $^{\mathrm{a}, \mathrm{e}}$, Jean-Pierre Féral ${ }^{\mathrm{a}, \mathrm{e}}$ \\ a Université de la Méditerranée, Centre d'Océanologie de Marseille, Station Marine d'Endoume, 13007 Marseille, France \\ ${ }^{\mathrm{b}}$ Université Montpellier 2, Place Eugène Bataillon, 34095 Montpellier, France \\ ${ }^{\text {c } C N R S ~ U M R ~ 5554-I S E M, ~ S t a t i o n ~ M e ́ d i t e r r a n e ́ e n n e ~ d e ~ l ' E n v i r o n n e m e n t ~ L i t t o r a l, ~} 34200$ Sète, France \\ ${ }^{\mathrm{d}}$ Institut de recherche pour le développement, Nouméa, New Caledonia \\ e CNRS UMR 6540-DIMAR, Centre d'Océanologie de Marseille, Station Marine d'Endoume, 13007 Marseille, France
}

\begin{abstract}
A B S T R A C T
Smooth-shelled mussels, Mytilus spp., have an antitropical distribution. In the Northern Hemisphere, the M. edulis complex of species is composed of three genetically well delineated taxa: M. edulis, M. galloprovincialis and M. trossulus. In the Southern Hemisphere, morphological characters, allozymes and intron length polymorphisms suggest that Mytilus spp. populations from South America and Kerguelen Islands are related to M. edulis and those from Australasia to M. galloprovincialis. On the other hand, a phylogeny of the $16 \mathrm{~S} r D N A$ mitochondrial locus demonstrates a clear distinctiveness of southern mussels and suggests that they are related to Mediterranean $M$. galloprovincialis. Here, we analysed the faster-evolving cytochrome oxidase subunit I locus. The divergence between haplotypes of populations from the two hemispheres was confirmed and was found to predate the divergence between haplotypes of northern M. edulis and M. galloprovincialis. In addition, strong genetic structure was detected among the southern samples, revealing three genetic entities that correspond to (1) South America and Kerguelen Island, (2) Tasmania, (3) New Zealand. Using the trans-Arctic interchange as a molecular clock calibration, we estimated the time since divergence of populations from the two hemispheres to be between 0.5 million years (MY) and 1.3 MY (average 0.84 MY). The contrasting patterns observed for the nuclear and the organelle genomes suggested two alternative, complex scenarios: two trans-equatorial migrations and the existence of differential barriers to mitochondrial and nuclear gene flow, or a single trans-equatorial migration and a view of the composition of the nuclear genome biased by taxonomic preconception.
\end{abstract}

\section{Introduction}

Smooth-shelled mussels (Mytilus edulis L., M. galloprovincialis Lmk., M. trossulus Gould) are among those emblematical marine invertebrates that have an antitropical distribution-i.e. present in the cold and temperate waters of both hemispheres but absent from the tropics (Briggs, 1987; Vermeij, 1992). As for other antitropically distributed species, the analysis of the genetic relationships between populations of the two hemispheres may allow to infer the sense and timing of trans-equatorial migration (Bowen and Grant, 1997). Although introgressive hybridization occurs in each pair of smooth-shell Mytilus species (Skibinski et al., 1983; Rawson and Hilbish, 1998; Bierne et al., 2003), the genetic composition of the three taxa is now globally well defined in the Northern Hemisphere (Koehn, 1991; Quesada et al., 1998a; Daguin, 2000).
Using allozyme and morphometric characters, McDonald et al. (1991) first assigned populations from South America and Kerguelen Islands to M. edulis and those from Australasia to M. galloprovincialis. Further analysis, which added nuclear DNA markers to the available allozyme loci, globally supported this assignment but highlighted the endemic particularities of southern Mytilus spp. (Daguin and Borsa, 2000; Borsa et al., 2007). For instance, Kerguelen mussels present a genome of mixed M. edulis and M. galloprovincialis ancestry while Tasmanian mussels possess a predominantly $M$. galloprovincialis genomic background introgressed by M. edulis alleles fixed at some loci, pointing to past introgression (Borsa et al., 2007). To date the divergence between southern and northern Mytilus spp., Hilbish et al. (2000) have inferred their phylogeny at the $16 \mathrm{~S}$ rDNA mitochondrial locus (16S). Most haplotypes from the Southern Hemisphere populations cluster into a single clade closely related to the clade D typical of Mediterranean M. galloprovincialis, and the divergence between the two clades supports a southward migration in the Pleistocene; South 
American populations are not differentiated from Australasian populations. In addition, some haplotypes typical of northern $M$. edulis were found in the Kerguelen population, suggesting a recent introduction (Hilbish et al., 2000). Levels of diversity and divergence observed at the 165 locus in Mytilus spp. are low and the resolution of the phylogenetic relationships among haplotypes is poor. The cytochrome oxidase subunit I (COI) gene evolves faster than the 16S rDNA (Mueller, 2006) and this holds true in Mytilus spp. (Wares and Cunningham, 2001; Riginos et al., 2004).

The aim of the present study was to pursue the work of Hilbish et al. (2000) by (i) increasing the sampling effort at the $16 S$ locus, especially in the Kerguelen population, where the nuclear genome is supposed to be the result of reticulated evolution, (ii) analysing the faster-evolving $\mathrm{COI}$ locus and (iii) re-evaluating relative divergence times between southern and northern Mytilus spp. mussels, as well as attempting absolute dating with this new dataset.

\section{Material and methods}

\subsection{Sampling and mtDNA sequencing}

Mussels were collected between 1997 and 2004 at 13 sampling sites in Italy (CHG, equal to sample CHI of Daguin et al. (2001)), Chile (CHL, MAU, PAT), South Africa (AFR), Kerguelen Islands (KER), Australia (AUS), Tasmania (CBL, SIM, HOB) and New Zealand (DUN, WHB, GRS). Details on sampling locations are in Table 1 and in legend to Fig. 1. Pieces of gill and mantle were preserved in $95 \%$ ethanol. DNA was extracted using Chelex $100^{\circ}$ chelating resin (Walsh et al., 1991). The $417 \mathrm{bp}$ fragment of the $16 \mathrm{~S}$ locus was amplified by polymerase chain reaction (PCR) using the two primers $16 S-R A\left(5^{\prime}\right.$ CGCCTGTTTATCAAAAACAT $\left.3^{\prime}\right)$ and $16 S-R B\left(5^{\prime}\right.$ CCGGTCTGAACTCAGATCACGT 3') (Palumbi et al., 1991). The PCR program consisted of $5 \mathrm{~min}$ at $95^{\circ} \mathrm{C}$, then 35 cycles of $95^{\circ} \mathrm{C}$ for $1 \mathrm{~min}, 54^{\circ} \mathrm{C}$ for $45 \mathrm{~s}, 72^{\circ} \mathrm{C}$ for $1 \mathrm{~min}$ and a final extension of 7 min at $72^{\circ} \mathrm{C}$. A 645 bp fragment of the COI gene was amplified using the forward primer LCO1490 (5' GGTCAACAAATCATAAAGA TATTGG $3^{\prime}$ ) (Folmer et al., 1994), the reverse primer AM-HCO (5' TAAACYTCAGGGTGMCCAAAAAAYCA $3^{\prime}$ ) and the same PCR program as above with an annealing temperature of $59{ }^{\circ} \mathrm{C}$. PCR products were sequenced directly. Only female mitochondrial sequences were considered in the present study. Chromatograms were inspected visually and the sequences were aligned using CLUSTALW (Thompson et al., 1994) implemented in BIOEDIT (Hall, 1999). $16 S$ and COI gene sequences were submitted to EMBL (http://www.embl-heidelberg.de/) under accession numbers AM904568-AM904606 and AM905146-AM905225, respectively (Table 1).

\subsection{Population genetics analysis}

Haplotype diversity and levels of nucleotide diversity estimated from the number of polymorphic sites $\left(\theta_{\mathrm{W}}\right.$; Watterson, $1975)$ and from pairwise differences $\left(\theta_{\pi}\right.$; Nei, 1987) were computed using DNAsp (Rozas et al., 2003). Genetic differentiation between populations was estimated with the $\Phi$-analogues (Excoffier et al., 1992) of Wright's (1965) F-statistics, by using the software ARLEQUIN 3.0 (Excoffier et al., 2005). The null distribution of pairwise $\Phi_{\mathrm{ST}}$ values under the hypothesis of no difference among populations was obtained by permutating haplotypes between populations. The $p$-value given by the test is the proportion of $\Phi_{\text {ST }}$ pseudo-values generated by random permutations that are larger than or equal to the observed value. In order to visualize the genetic similarities among samples, non-metric multidimensional scaling was used on the matrix of $\Phi_{\mathrm{ST}}$ values (MDS; Kruskal and Wish, 1978).

\subsection{Phylogenetic analysis}

To our sequence set, we added the northern and southern Mytilus haplotypes of the $16 \mathrm{~S}$ locus and northern haplotypes of the COI gene available from the literature and from the EMBL database. The sources of the complete sequence set are detailed in Table 1 . These sequences were respectively $405 \mathrm{bp}$ and $384 \mathrm{bp}$ long.

Phylogenetic reconstructions were performed using distance and maximum-likelihood approaches. The most appropriate model of evolution as determined by MrAIC (Nylander, 2004) was the Tamura-Nei nucleotide substitution model (TN93; Tamura and Nei, 1993). Distance trees were constructed with the neighbourjoining (NJ) algorithm using TN93 distances with MEGA version 3.1 (Kumar et al., 2004). Maximum-likelihood (ML) trees were built using PHYML (Guindon and Gascuel, 2003). Levels of support of tree nodes were determined using 1000 and 100 bootstrap replications of the original data for $\mathrm{NJ}$ and ML methods, respectively.

\subsection{Estimating the time of the trans-equatorial migration}

Mutation rate constancy at the COI locus in smooth-shelled mussels Mytilus spp. was checked using Tajima's (1993) test of relative rate implemented in MEGA 3.1. To perform this test, we used M. californianus (Accession No. U68776) as outgroup, as it represents the closest known taxon to the smooth-shelled mussels. To estimate the net nucleotide divergence, $d$, we assumed that the ancestral coalescence time was similar to the present one and estimated $\theta_{\pi}$ from the available samples. Then, $\theta_{\pi} / 2$ was subtracted from the average divergence $d_{x y}$ (Nei and Li, 1979). Among the available samples, we used the five largest samples (all with size greater than 15 individuals), including two samples from the Southern Hemisphere (PAT and KER, AM905187-AM905211), two samples of $M$. edulis from Sweden (AY723897-AY723917) and Nova Scotia (AF241951-AF24195157, AY130016-AY130023, AY723881-AY723887, AY723889, AY723890) and a sample of $M$. trossulus (AY130061-AY130067, AF242027-AF242029, AF242031AF242035). We used the opening of the Bering Strait, 3.5 million years (MY) ago as a calibration point to date the divergence between $M$. trossulus and North Atlantic M. edulis populations, following Wares and Cunningham (2001) and Riginos et al. (2004). Although the validity of this hypothesis can be discussed, it provides at least a basis for comparison with other studies.

\section{Results}

\subsection{Population genetics of southern Mytilus spp. mussels}

Among the 224 sequences at the 165 locus, 20 haplotypes with 19 polymorphic sites were identified; whereas among the 171 sequences of the $\mathrm{COI}$ gene, we scored 59 haplotypes, with 104 polymorphic sites. Consequently, the level of polymorphism expressed by nucleotide and haplotype diversities, was much higher for the COI locus than for the 165 locus (Table 2). Nucleotidic variation at the 165 locus was low and mainly composed of singleton mutations, while the diversity of the COI locus was higher. Genetic differentiation between populations was observed at both loci but was stronger at the COI locus (global $\left.F_{\mathrm{ST}}=0.8, p<0.0001\right)$ than at the $16 \mathrm{~S}$ locus. Fig. 2 depicts the genetic differences between southern samples for the COI locus. Four groups of samples sharing low $\Phi_{\mathrm{ST}}$ values appeared, three of which correspond to geographic regions: South America, Tasmania and New Zealand. The fourth group was composed of geographically separated samples (CHL, AFR, AUS). Non-significant $\Phi_{\mathrm{ST}}$ values were observed among samples from New Zealand, between two samples from Tasmania (CBL and SIM), and between CHL and AFR (Fig. 2). 
Table 1

Mytilus spp. nucleotide sequences of $\mathrm{COI}$ and $16 S$ loci used in the present study. $N$, sample size

\begin{tabular}{|c|c|c|c|c|c|}
\hline Locus species & Sampling locations & $N$ & Name of sequences & GenBank Accession Nos. & References \\
\hline \multicolumn{6}{|l|}{$16 S$} \\
\hline M. trossulus & Northeastern Pacific: Alaska, Oregon & 5 & Tshel, Tore, Tak & AY636148, AY636150-AY636153 & Rawson (2005) \\
\hline M. trossulus & Northeastern Pacific: Oregon & 3 & TU1, TU2, TU3 & U22879-U22881 & Rawson and Hilbish (1995) \\
\hline M. edulis & Northwestern Atlantic: Delaware & 3 & $\mathrm{E} 1, \mathrm{E} 3, \mathrm{E} 4$ & U22864, U22866, U22867 & Rawson and Hilbish (1995) \\
\hline M. edulis & Northwestern Atlantic: Delaware & 6 & EDe6-11 & $\begin{array}{l}\text { AF023542, AF023544, AF023545, } \\
\text { AF023547, AF023549, AF023550 }\end{array}$ & Rawson and Hilbish (1998) \\
\hline M. edulis & - & 1 & Ew22F & AY350784 & Cao et al. (2004) \\
\hline M. edulis & - & 1 & E38 & AJ293738 & Quesada et al. (2003) \\
\hline M. galloprovincialis & Mediterranean: Sète (France) & 5 & GFr1-5 & $\begin{array}{l}\text { AF023552, AF023554, AF023556, } \\
\text { AF023558, AF023560 }\end{array}$ & Rawson and Hilbish (1998) \\
\hline M. galloprovincialis & Atlantic: Spain & 3 & GSp1-3 & AF023563-AF023565 & Rawson and Hilbish (1998) \\
\hline M. galloprovincialis & Northeastern Pacific: San Diego, CA & 2 & GM-1, GM-2 & U22884-U22885 & Rawson and Hilbish (1995) \\
\hline M. galloprovincialis & Northeastern Pacific: San Diego, CA & 7 & GAL2-4, GAL6-9 & U22870-U22872, U22874-U22877 & Rawson and Hilbish (1995) \\
\hline M. galloprovincialis & - & 1 & Mgal-mtgenome & AY497292 & Mizi et al. (2005) \\
\hline M. galloprovincialis & Chioggia, Italy & 9 & $\mathrm{CHG}$ & AM904603-AM904606 & Present study \\
\hline Mytilus sp. & Northeastern Atlantic: Ex River, UK & 2 & HEx1, HEx2 & AF023589-AF023590 & Rawson and Hilbish (1998) \\
\hline Mytilus sp. & $\begin{array}{l}\text { Northeastern Atlantic: Whitsand Bay, } \\
\text { UK }\end{array}$ & 8 & HWb1-8 & $\begin{array}{l}\text { AF023572, AF023574, AF023576, } \\
\text { AF023577, AF023579, AF023581, } \\
\text { AF023582, AF023584 }\end{array}$ & Rawson and Hilbish (1998) \\
\hline Mytilus sp. & $\begin{array}{l}\text { Southern Ocean: Chile, Falklands, } \\
\text { Kerguelen, Australia, New Zealand }\end{array}$ & 20 & $\mathrm{CH}, \mathrm{FA}, \mathrm{K}, \mathrm{AU}, \mathrm{NZ}$ & AF179443-AF179462 & Hilbish et al. (2000) \\
\hline Mytilus sp. & Dichato, Chile & 8 & $\mathrm{CHL}$ & АM904600-АM904602 & Present study \\
\hline Mytilus sp. & Maullin, Chile & 10 & MAU & AM904582-AM904584 & Present study \\
\hline Mytilus sp. & Canal de las Montañas, Patagonia, Chile & 39 & PAT & АM904585-АM904588 & Present study \\
\hline Mytilus sp. & Pater Noster Bay, South Africa & 8 & AFR & АM904595-АM904599 & Present study \\
\hline Mytilus sp. & Kerguelen islands & 99 & KER & AM904589-AM904590 & Present study \\
\hline Mytilus sp. & Nedlands, Australia & 5 & AUS & АM904591-АM904594 & Present study \\
\hline Mytilus sp. & Cloudy Bay lagoon, Tasmania & 9 & CBL & AM904577, АM904578 & Present study \\
\hline Mytilus sp. & Simpson's Bay, Tasmania & 6 & SIM & AM904579-AM904581 & Present study \\
\hline Mytilus sp. & Hobart, Tasmania & 9 & HOB & AM904576 & Present study \\
\hline Mytilus sp. & Wellington Harbour, New Zealand & 10 & WHB & AM904570-AM904572 & Present study \\
\hline Mytilus sp. & Dunedin, New Zealand & 10 & DUN & AM904568, AM904569 & Present study \\
\hline Mytilus sp. & George Sound, New Zealand & 10 & GRS & AM904573-AM904575 & Present study \\
\hline \multicolumn{6}{|l|}{$\mathrm{COI}$} \\
\hline M. trossulus & Mahone Bay, Nova Scotia & 3 & 669NS, 671NS, 672NS & AY130061-AY130063 & Riginos et al. (2004) \\
\hline M. trossulus & Penn Cove, WA, USA & 4 & $\begin{array}{l}\text { 764WA, 766WA, 768WA, } \\
\text { 769WA }\end{array}$ & AY130064-AY130067 & \\
\hline M. trossulus & North eastern Pacific & 2 & MMT & AF242031-AF242032 & $\begin{array}{l}\text { Wares and Cunningham } \\
\text { (2001) }\end{array}$ \\
\hline M. trossulus & North America & 6 & JMT, PMT & $\begin{array}{l}\text { AF242027-AF242029, AF242033- } \\
\text { AF242035 }\end{array}$ & $\begin{array}{l}\text { Wares and Cunningham } \\
\text { (2001) }\end{array}$ \\
\hline M. edulis & $\begin{array}{l}\text { Northwestern Atlantic: Newfoundland, } \\
\text { Nova Scotia, Maine, North Carolina, } \\
\text { Rhode Island, Massachusetts }\end{array}$ & 46 & NF, NS, ME, NC, RI, MA & AF241936-AF241981 & $\begin{array}{l}\text { Wares and Cunningham } \\
\text { (2001) }\end{array}$ \\
\hline M. edulis & Northwestern Atlantic: Massachusetts & 4 & MA & $\begin{array}{l}\text { AY101417, AY101425, AY101426, } \\
\text { AY101429 }\end{array}$ & Riginos et al. (2004) \\
\hline M. edulis & $\begin{array}{l}\text { Northwestern Atlantic: Newfoundland, } \\
\text { Nova Scotia, Maine, Massachusetts, } \\
\text { North Carolina }\end{array}$ & 40 & $\mathrm{NF}, \mathrm{NS}, \mathrm{ME}, M A, N C$ & $\begin{array}{l}\text { AY130011-AY130037, AY723880- } \\
\text { AY723892 }\end{array}$ & Riginos et al. (2004) \\
\hline M. edulis & $\begin{array}{l}\text { Northeastern Atlantic: Iceland, Norway, } \\
\text { France }\end{array}$ & 45 & Ice, No, Fr & AF241982-AF242026 & $\begin{array}{l}\text { Wares and Cunningham } \\
\text { (2001) }\end{array}$ \\
\hline M. edulis & $\begin{array}{l}\text { Northeastern Atlantic: Iceland, Norway, } \\
\text { Sweden }\end{array}$ & 28 & Ice, No, Sw & $\begin{array}{l}\text { AY723893-AY723901, AY723903- } \\
\text { AY723917, AY101421-AY101424 }\end{array}$ & Riginos et al. (2004) \\
\hline M. edulis & $\begin{array}{l}\text { Northeastern Atlantic: Ireland, Finland, } \\
\text { France }\end{array}$ & 21 & Ire, Fi, Fr & $\begin{array}{l}\text { AY723918-AY723922, AY130038- } \\
\text { AY130053 }\end{array}$ & - \\
\hline M. galloprovincialis & Greece: Samos & 7 & GR & AY130054-AY130060 & - \\
\hline M. galloprovincialis & - & 1 & Mgal-mtgenome & AY497292 & Mizi et al. (2005) \\
\hline M. galloprovincialis & Chioggia, Italy & 10 & $\mathrm{CHG}$ & АM905220-АM905225 & Present study \\
\hline Mytilus sp. & Dichato, Chile & 9 & $\mathrm{CHL}$ & AM905174-AM905179 & Present study \\
\hline Mytilus sp. & Maullin, Chile & 7 & MAU & AM905180-AM905186 & Present study \\
\hline Mytilus sp. & $\begin{array}{l}\text { Canal de las Montañas, Patagonia, } \\
\text { Chile }\end{array}$ & 20 & PAT & AM905187-AM905195 & Present study \\
\hline Mytilus sp. & Pater Noster Bay, South Africa & 7 & AFR & АM905216-АM905219 & Present study \\
\hline Mytilus sp. & Kerguelen islands & 83 & KER & AM905196-AM905211 & Present study \\
\hline Mytilus sp. & Nedlands, Australia & 7 & AUS & AM905212-AM905215 & Present study \\
\hline Mytilus sp. & Cloudy Bay lagoon, Tasmania & 5 & CBL & АM905161-АM905164 & Present study \\
\hline Mytilus sp. & Simpson's Bay, Tasmania & 3 & SIM & AM905165-AM905167 & Present study \\
\hline Mytilus sp. & Hobart, Tasmania & 8 & НОВ & АM905168-АM905173 & Present study \\
\hline Mytilus sp. & Wellington Harbour, New Zealand & 7 & WHB & AM905149-AM905154 & Present study \\
\hline Mytilus sp. & Dunedin, New Zealand & 6 & DUN & АM905146-АM905148 & Present study \\
\hline Mytilus sp. & George Sound, New Zealand & 9 & GRS & АM905155-АM905160 & Present study \\
\hline
\end{tabular}

Hyphens indicate missing informations. 


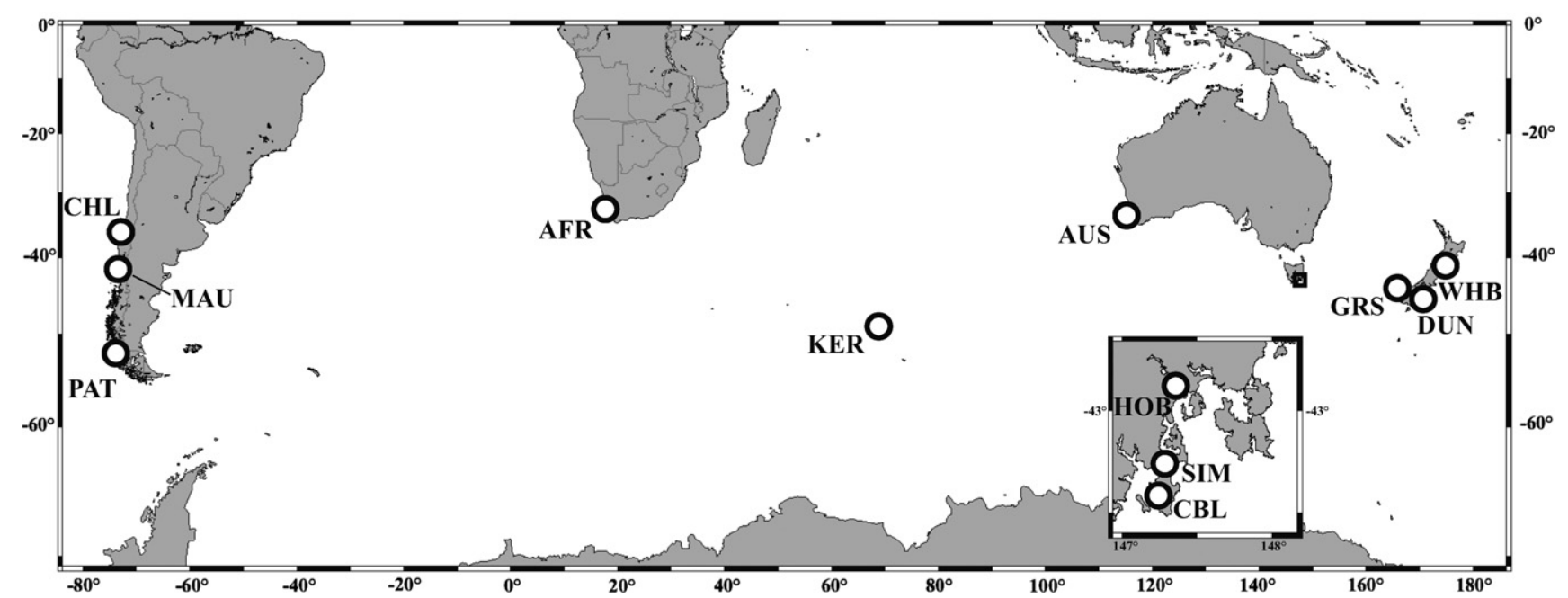

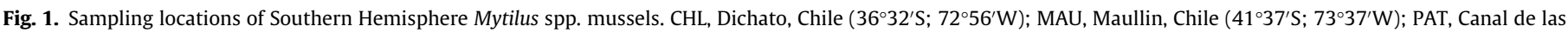

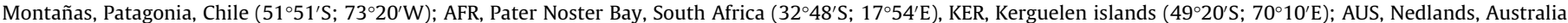

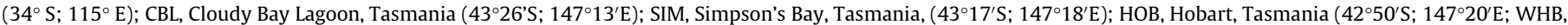
Wellington Harbour, New Zealand ( $\left.41^{\circ} 20^{\prime} \mathrm{S} ; 174^{\circ} 48^{\prime} \mathrm{E}\right)$; DUN, Dunedin, New Zealand $\left(45^{\circ} 54^{\prime} \mathrm{S} ; 170^{\circ} 30^{\prime} \mathrm{E}\right)$; GRS, George Sound, New Zealand $\left(44^{\circ} 52^{\prime} \mathrm{S}\right.$; $\left.167^{\circ} 20^{\prime} \mathrm{E}\right)$.

Table 2

Haplogroup frequencies in Southern Hemisphere Mytilus spp. populations and parameters of nucleotide sequence variability at mitochondrial loci COI and $16 \mathrm{~S}$

\begin{tabular}{|c|c|c|c|c|c|c|c|c|c|c|c|c|}
\hline \multirow[t]{2}{*}{ Locus Haplogroup } & \multicolumn{12}{|l|}{ Sample } \\
\hline & $\mathrm{CHL}$ & MAU & PAT & AFR & KER & AUS & SIM & CBL & НОВ & WHB & DUN & GRS \\
\hline \multicolumn{13}{|l|}{$16 S$} \\
\hline $\mathrm{N}$ & 1 & 0 & 0 & 1 & 0 & 1 & 0 & 0 & 0 & 0.2 & 0 & 0 \\
\hline S & 0 & 1 & 1 & 0 & 1 & 0 & 1 & 1 & 1 & 0.8 & 1 & 1 \\
\hline$H_{\mathrm{d}}$ & 0.464 & 0.51 & 0.24 & 0.86 & 0.02 & 0.90 & 0.73 & 0.22 & 0 & 0.62 & 0.20 & 0.38 \\
\hline$\theta_{\pi}$ & 0.00612 & 0.0013 & 0.0006 & 0.00788 & 0.00005 & 0.00719 & 0.00208 & 0.00053 & 0 & 0.0038 & 0.00048 & 0.00096 \\
\hline$\theta_{w}$ & 0.00639 & 0.0017 & 0.0017 & 0.00647 & 0.00046 & 0.00806 & 0.0021 & 0.00088 & 0 & 0.0017 & 0.00085 & 0.00339 \\
\hline$(\mathrm{N})$ & $(8)$ & $(10)$ & (39) & $(8)$ & (99) & (5) & (6) & (9) & (9) & $(10)$ & $(10)$ & $(10)$ \\
\hline \multicolumn{13}{|l|}{$\mathrm{COI}$} \\
\hline $\mathrm{N}$ & 1 & 0 & 0 & 1 & 0 & 1 & 0 & 0 & 0 & 0.14 & 0 & 0 \\
\hline S1 & 0 & 1 & 1 & 0 & 1 & 0 & 0 & 0 & 0 & 0 & 0 & 0 \\
\hline S2 & 0 & 0 & 0 & 0 & 0 & 0 & 0 & 0 & 0 & 0.86 & 1 & 1 \\
\hline S3 & 0 & 0 & 0 & 0 & 0 & 0 & 1 & 1 & 1 & 0 & 0 & 0 \\
\hline$H_{\mathrm{d}}$ & 0.889 & 1 & 0.75 & 0.81 & 0.85 & 0.81 & 1 & 0.90 & 0.893 & 0.95 & 0.60 & 0.83 \\
\hline$\theta_{\pi}$ & 0.01559 & 0.00753 & 0.00453 & 0.01521 & 0.00341 & 0.01801 & 0.00413 & 0.00279 & 0.00604 & 0.02110 & 0.00270 & 0.00172 \\
\hline$\theta_{w}$ & 0.01711 & 0.00949 & 0.00524 & 0.01392 & 0.00590 & 0.01455 & 0.00413 & 0.00298 & 0.00777 & 0.00285 & 0.00272 & 0.02974 \\
\hline
\end{tabular}

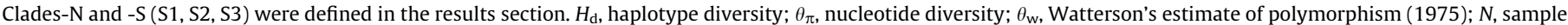

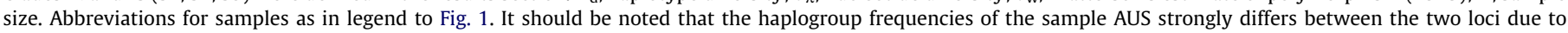
different subsets of individuals successfully sequenced.

\subsection{Phylogenetic relationships}

The phylogenetic relationships among Mytilus spp. haplotypes are presented in Fig. 3A (16S locus) and Fig. 3B (COI locus). The topology of the ML tree was identical to that of the NJ tree as far as nodes supported by bootstrap scores over $50 \%$ are concerned. Only the NJ trees were presented, with the bootstrap scores of each $\mathrm{NJ}$ and ML phylogenies indicated on the branches. Tree nodes generally were supported by higher bootstrap values in the COI tree than in the $16 S$ tree. The M. trossulus sample was not polluted by introgression and we were able to use it as a robust closely related outgroup. In agreement with previous results (Hilbish et al., 2000), the majority of haplotypes sampled in the Southern Hemisphere clustered in a single clade. We called this clade ' $\mathrm{S}$ ' (for 'Southern'). Clade $\mathrm{S}$ was distinct from the haplogroup made of all the haplotypes sampled in the Northern Hemisphere and forming a clade here called N ('Northern'). This result was supported in the COI tree (Fig. 3B) with higher bootstrap values than in the $16 \mathrm{~S}$ tree (Fig. 3A).
Clade- $N$ haplotypes were present in four populations of the Southern Hemisphere: Chile ( $\mathrm{CHL}$ ), South Africa (AFR), Western Australia (AUS) and New Zealand (WHB). Samples CHL, AFR and AUS were exclusively composed of clade-N haplotypes (Table 2) and sample WHB was polymorphic for clade-S and clade-N haplotypes, the clade- $\mathrm{N}$ haplotypes being sampled in lower frequency (Table 2). Finally, the analysis of the COI locus revealed that the clade $\mathrm{S}$ can be subdivided into three sub-clades, two of which were well supported, corresponding to three geographic regions: S1 (South America and Kerguelen), S2 (New Zealand) and S3 (Tasmania).

\subsection{Dating the trans-equatorial migration}

Tajima's relative rate tests were not significant $(p>0.05)$. Therefore, the existence of different rates of evolution between lineages was not demonstrated and we consequently assumed a clock-like rate of evolution. The Table 3 details the different steps that led to the estimation of the net nucleotide divergence between 


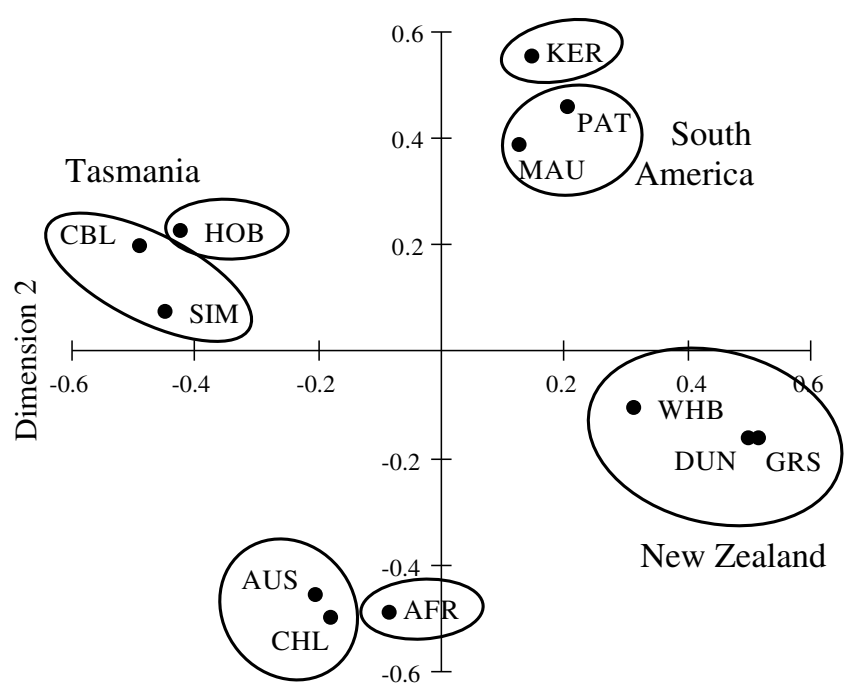

Dimension 1

Fig. 2. Bidimensional representations of multidimensional scaling (MDS) based on $\Phi$ st values calculated between all pairs of southern samples at COI locus (stress 0.17). Circles group samples significantly differentiated from excluded sample and between which $\Phi$ st values are non-significant $(P>0.05)$. See Fig. 1 for sample abbreviations.

the $M$. trossulus sample and the other samples, $d_{(1)}$, and the one between the $M$. edulis samples (from Sweden and/or Nova Scotia) and PAT and KER, $d_{(2)}$. Since the ratio of the net divergences was 4.17 and assuming that the divergence time between $M$. trossulus and other populations was 3.5 MY, we estimated the trans-equatorial migration event to be $0.84 \mathrm{MY}(0.54-1.31 \mathrm{MY})$ old.

\section{Discussion}

As previously emphasized in the Northern Hemisphere, the COI locus appeared to be a more informative marker than the $16 \mathrm{~S}$ locus for phylogeographical studies of Mytilus in the Southern Hemisphere. The divergence between Southern- and Northern-Hemisphere haplotypes predates the divergence of haplogroups typical of modern M. edulis and M. galloprovincialis. However, gene trees are not species trees (Nichols, 2001), particularly in a species complex with hybridization and introgression as observed in smoothshelled Mytilus. The results obtained with the single mitochondrial genome do not allow us to infer a general history of population divergence. The present results can nonetheless be discussed in the light of previously published results from allozymes and nuclear-DNA length polymorphisms.

\subsection{Strong genetic structure among Mytilus spp. populations of the Southern Hemisphere}

Three groups of samples can be recognized in the Southern Hemisphere: (i) samples exclusively composed of clade-N haplotypes, (ii) samples exclusively composed of clade-S haplotypes and (iii) samples that are polymorphic for both. We observed the first kind of samples in Chile, South Africa and Western Australia. These populations likely originate from recent introductions. The recent introduction of $M$. galloprovincialis mussels in South Africa has already been reported (Grant and Cherry, 1985; McDonald et al., 1991; Daguin and Borsa, 2000). Recently introduced M. galloprovincialis populations have also been reported in Eastern Asia (Wilkins et al., 1983; Lee and Morton, 1985; Daguin and Borsa, 2000), California (Mc Donald and Koehn, 1988; Daguin and Borsa,
2000) and Chile (Daguin and Borsa, 2000). Here, we report the probable introduction of mussels from the Northern Hemisphere to Western Australia. The phylogenetic position of haplotypes from sample AUS indicates that these mussels are once again $M$. galloprovincialis. However, the same sample appeared to be rather intermediate between Southern- (Tasmania and New Zealand) and Northern Hemisphere M. galloprovincialis at the nuclear locus mac-1 (Daguin and Borsa, 2000). Further analyses will be needed to clarify the genetic composition of mussels from Western Australia. Samples of the second kind, exclusively composed of clade-S haplotypes, can be considered to belong to southern endemic populations. These samples comprised three genetic entities that reached reciprocal monophyly and corresponded to distinct regions: South America (MAU and PAT) and Kerguelen with haplotypes of the clade S1, New Zealand (DUN and GRS) with haplotypes of the clade S2 and Tasmania (HOB, SIM and CBL) with haplotypes of the clade S3 (Fig. 3B). In contrast to Hilbish et al. (2000) who sampled exclusively clade- $\mathrm{N}$ haplotypes in their small sample $(N=5)$ from the Kerguelen Islands, we did not sample any clade-N haplotypes in our Kerguelen sample $(N=99)$. Population structure was also observed to a lesser extent among the three clade-S1 samples (Fig. 2), as well as between HOB and the two other samples from Tasmania (Fig. 2). The level of population differentiation was not well correlated with geographic distance. For instance, genetic differences between Tasmania and New Zealand populations were stronger than between South America and Kerguelen, in spite of being geographically closer. One explanation relies on the geographic fragmentation of landmasses, together with present and past routes of major oceanic currents that go through the mid-latitudes of the Southern Hemisphere. For instance, although the Kerguelen archipelago is isolated by the polar front and the Antarctic circumpolar current, latitudinal displacements of the front may have connected the Kerguelen Islands to South America in the recent past (Hollyday and Read, 1998). Conversely, the eastern seaboard of Tasmania is affected by the East Australian Current, whose southern extremity pinches off warm-core anticlockwise eddies drifting south near the margin of the continental shelf through the colder waters of the Southern Ocean (Nilsson and Cresswell, 1981). Southeastern Tasmania may therefore be isolated by local oceanic circulation. Alternatively, barriers to mtDNA exchange may be genetic instead of geographic as it has previously been suggested for populations of the Northern Hemisphere (Quesada et al., 1995; Riginos et al., 2004). Finally, we observed a sample from New Zealand (WHB) in which clade-N haplotypes occur at low frequency within a population otherwise composed of clade$\mathrm{S}$ haplotypes. Unfortunately, it is not possible with mtDNA haploid data to distinguish admixture (whereby northern migrants do not reproduce in panmixia with native Southern-Hemisphere mussels) from introgression (whereby northern alleles have invaded the genetic background of southern natives).

\subsection{The isolation between mtDNA lineages of populations from the} two hemispheres predates the divergence between M. edulis and M. galloprovincialis haplotypes

Hilbish et al. (2000) previously showed with the 165 locus that haplotypes from endemic Southern-Hemisphere Mytilus spp. clustered together into a single clade. In their topology the southern clade was related to haplotypes sampled in Mediterranean M. galloprovincialis. With our new dataset for the 165 locus, we obtained a slightly different although poorly supported topology, where the clade-S branched ancestrally to the clade N. We interpret the discrepancy between the $16 \mathrm{~S}$ tree of Hilbish et al. (2000) and ours by the lack of phylogenetic signal with this locus. Much better statistical support was obtained with the $\mathrm{COI}$ locus. The $\mathrm{COI}$ tree not only reveals the distinction between endemic southern and 
A. $16 \mathrm{~S}$

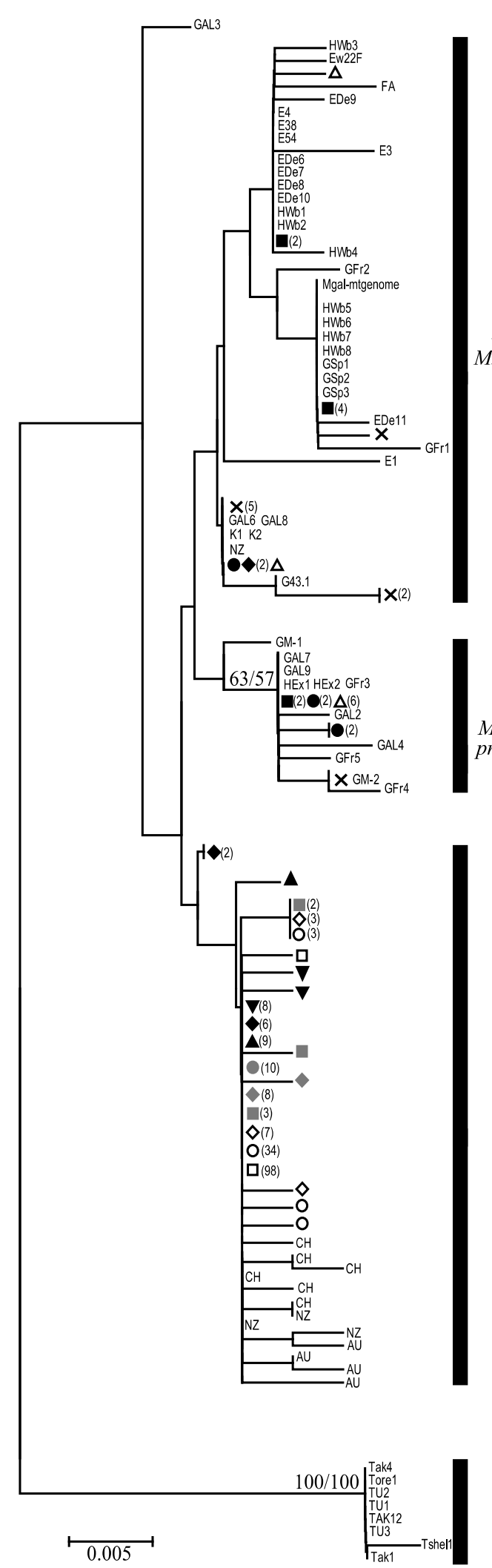

B. $\mathrm{COI}$

A

M. edulis

D

M. gallo-

provincialis

$\mathrm{N}$

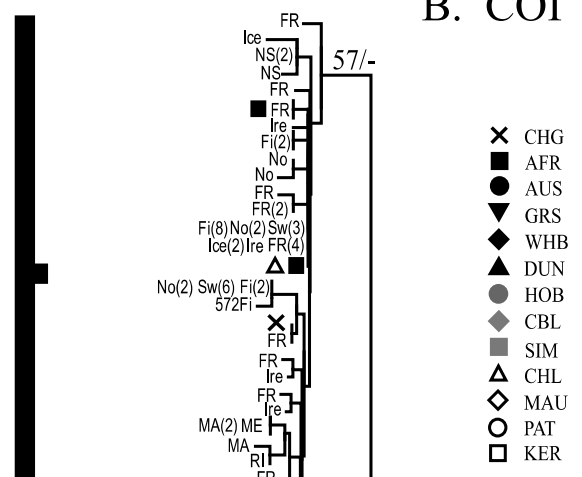

FR

$M A$

Mgal-mtgenome

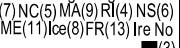

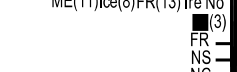

ME

ME(2)

MA(4) ME(3) NS(2) N

(FR

$\mathrm{NS}(4) \mathrm{N}$

$\mathrm{Sw}(3)$

MA NCH

NS(6)

SW

Sw(2)

$\mathbf{X}(4) \mathrm{GR}(3)$

$\times$ GR $795 / 94$
S

New Zealand

\section{$\mathrm{S} 2$}

$\times$ GR

(2) $\Delta$ (2)

GR $\mathbf{X}$

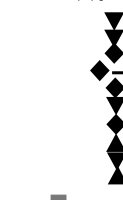

S3

Tasmania

S1

South America

\& Kerguelen

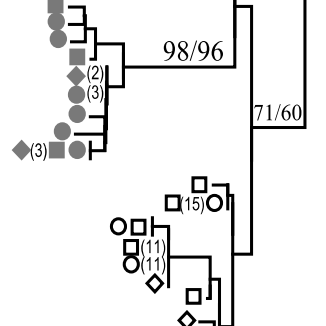

$99 / 89$
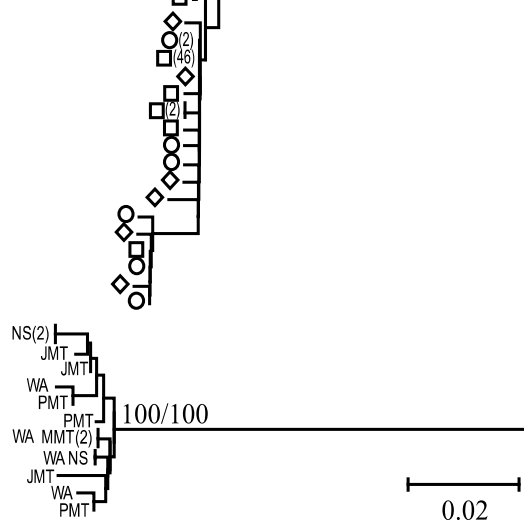

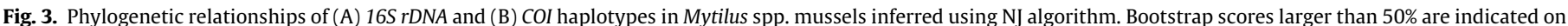

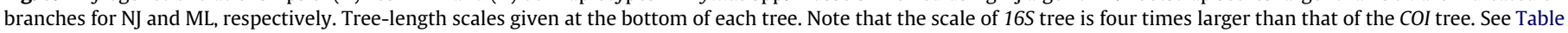
1 for site abbreviations. 
Table 3

Estimation of relative divergence between Mytilus spp. samples from Northern and Southern Hemispheres

\begin{tabular}{lcll}
\hline Comparison, Parameter & Average & Min. & Max. \\
\hline$\theta_{\pi} / 2$ & 0.0046 & $0.0018( \pm 0.0005)$ & $0.0076( \pm 0.0015)$ \\
$\begin{array}{l}\text { M. trossulus } v \text { s. any other sample } \\
d_{x y} \\
d_{(1)}\end{array} \quad 0.146$ & $0.144( \pm 0.012)$ & $0.149( \pm 0.013)$ \\
M. edulis ${ }^{*}$ vs. any other sample & 0.141 & 0.123 & 0.161 \\
$d_{x y}$ & 0.040 & $0.036( \pm 0.002)$ & $0.043( \pm 0.004)$ \\
$d_{(2)}$ & 0.035 & 0.025 & 0.046 \\
$d_{(1)} / d_{(2)}$ & 4.17 & 2.67 & 6.44
\end{tabular}

$\theta_{\pi} / 2$ was calculated for each of the five samples (M. trossulus, M. edulis from Sweden and from Nova Scotia, PAT and KER). $d_{\mathrm{xy}}$ : average divergence; $d$ : net nucleotide divergence. For each parameter, the average was calculated from all possible values, among which are the indicated extreme values (min., max.). Standard error is indicated in brackets.

M. edulis from Sweden or Nova Scotia.

northern haplotypes but also indicates that this dichotomy predates the divergence of typical $M$. edulis and $M$. galloprovincialis haplotypes. An attempt to date the divergence between populations of the two hemispheres led to an estimate of $0.84 \mathrm{MY}$ (0.54-1.31 MY). This divergence dates from the Pleistocene (0.01-1.8 MY) as already inferred by Hilbish et al. (2000).

\subsection{Can we reconcile mitochondrial and nuclear data into a single scenario?}

From the genetic data on southern Mytilus spp. mussels provided by markers of various types, two conflicting scenarios of trans-equatorial migration can be inferred. The first scenario is supported by allozymes (McDonald et al., 1991) and two introns (mac-1 and EFbis, Daguin, 2000; Borsa et al., 2007). It distinguishes South American and Kerguelen populations that share similarities with M. edulis, from Australasian populations (Australia, New Zealand, Tasmania) that share similarities with M. galloprovincialis. This pattern suggests two independent trans-equatorial migrations, one each from $M$. edulis-like and M. galloprovincialis-like populations that would have occurred after the separation of the two species. The second scenario comes from the most parsimonious interpretation of the mtDNA data and suggests a unique transequatorial migration, which would be older than the coalescence of all the northern haplotypes.

Although conflicting at first view, cyto-nuclear discordance may reveal interesting details about the evolution of species and may have important consequences for evolutionary inference if undetected (Sang and Zong, 2000; Funk and Omland, 2003). We here propose to consider how the scenario suggested by one genome (nuclear vs. organelle) can fit the results observed with the other one.

Under the first scenario, we need to explain why the divergence of the southern and northern haplotypes appears more ancient than the divergence between typical $M$. edulis and M. galloprovincialis haplotypes, and why the two trans-equatorial migrations did not result in a paraphyletic pattern of the southern and northern lineages. Pre-divergence coalescence can be invoked to explain that the southern clade branches deeply in the tree. The present $m t D N A$ differences between $M$. edulis and $M$. galloprovincialis are not strong and one can hypothesize that they were less pronounced at the time of migrations. Post-migration lineage sorting would then have resulted in the successful retention of an old lineage in southern populations-i.e. a gene tree that does not match the population tree. However, this hypothesis of mismatched lineage sorting does not explain the reciprocal monophyly of the clades $\mathrm{S}$ and $\mathrm{N}$ under the two-migration hypothesis. This is why one may invoke the effect of semi-permeable barriers to gene flow either in the northern or in the southern populations. The barrier to gene flow between M. edulis and M. galloprovincialis is semi-permeable (Skibinski et al., 1983; Bierne et al., 2002) and strong mitochondrial introgression has been documented (Quesada et al., 1998b). The flow of mtDNA genes is likely to have continued while the flow of some nuclear genes was already impeded. Alternatively, hybridization and introgression within the Southern Hemisphere would have erased the signature of one trans-equatorial migration on the mtDNA genome. Be they localised in the North or in the South, the presence of semi-permeable barriers leading to differential organelle and nuclear gene flow greatly helps in reconciling the data obtained with the two genomes under the twomigration scenario.

The second scenario consists of a single southward trans-equatorial migration early in the Pleistocene before the presumed speciation of M. edulis and M. galloprovincialis. Under this scenario the distinction, based on nuclear markers, of M. edulis-like and M. galloprovincialis-like mussels in the Southern Hemisphere would be merely virtual, constrained by human's wish to always assign new samples to reference populations assumed to represent the genetic composition of a given taxon (e.g. Hey, 2001a,b). In addition, the few nuclear markers used to date might suffer from an ascertainment bias as they have often been chosen to discriminate $M$. edulis and M. galloprovincialis populations in the Northern Hemisphere. However, it is difficult to rule out that the high stochasticity of the coalescence process on a limited number of loci did not result in some populations being apparently closely related to one of the references.

\section{Acknowledgments}

We are very grateful to C. Gilbert, J. Beesley, J.P.A. Gardner, C. Perrin, C. J. Morales and S. Faugeron, and C. Riquelme and D. Moraga for providing mussels from, respectively, Paternoster Bay (South Africa), Australia, Wellington Harbour, Dunedin and George Sound (NZ), Maullin and Dichato (Chile); to J. Lallemand, R.D. Ward and $\mathrm{H}$. Weimerskich for helpful assistance to P.B. in Tasmania; to C. Daguin for providing a number of DNA extracts and to $C$. Rocher for lab work aid. We also thank the French Polar Institute (IPEV) for fieldwork logistics in Kerguelen (program 195) and Gilles Santantonio for fieldwork logistic in Patagonia. We also thank two anonymous reviewers for helpful comments on the manuscript.

\section{References}

Bierne, N., Borsa, P., Daguin, C., Jollivet, D., Viard, F., Bonhomme, F., David, P., 2003 Introgression patterns in the mosaic hybrid zone between Mytilus edulis and $M$. Galloprovincialis. Mol. Ecol. 12, 447-461.

Bierne, N., David, P., Langlade, A., Bonhomme, F., 2002. Can habitat specialisation maintain a mosaic hybrid zone in marine bivalves? Mar. Ecol. Prog. Ser. 245 157-170.

Borsa, P., Daguin, C., Bierne, N., 2007. Genomic reticulation indicates mixed ancestry in Southern Hemisphere Mytilus spp. mussels. Biol. J. Linn. Soc. 92, 747-754.

Bowen, B.W., Grant, W.S., 1997. Phylogeography of the sardines (Sardinops spp.): assessing biogeographical models and populations histories in temperate upwelling zones. Evolution 51, 1601-1610.

Briggs, J.C., 1987. Antitropical distribution and evolution in the Indo-West Pacific Ocean. Syst. Zool. 36, 237-247.

Cao, L., Kenchington, E., Zouros, E., Rodakis, G.C., 2004. Evidence that the large noncoding sequence is the main control region of maternally and paternally transmitted mitochondrial genomes of the marine mussel(Mytilus spp.). Genetics 167, 835-850

Daguin, C., 2000. Phylogéographie des moules du complexe d'espèces Mytilus edulis Unpublished Ph.D. Dissertation, Université Montpellier 2, Montpellier, France.

Daguin, C., Bonhomme, F., Borsa, P., 2001. The zone of sympatry and hybridization of Mytilus edulis and M. galloprovincialis, as described by intron length polymorphism at locus mac-1. Heredity $86,342-354$.

Daguin, C., Borsa, P., 2000. Genetic relationships of Mytilus galloprovincialis Lmk Populations worldwide: evidence from nuclear-DNA markers. Geol. Soc. Lond. Spec. Publ. 177, 389-397. 
Excoffier, L., Laval, G., Schneider, S., 2005. Arlequin ver. 3.0: An integrated software package for population genetics data analysis. Evol. Bioinform. Online 1, 47-50.

Excoffier, L., Smouse, P., Quattro, J., 1992. Analysis of molecular variance inferred from metric distances among DNA haplotypes: application to human mitochondrial DNA restriction data. Genetics 131, 479-491.

Folmer, O., Black, M., Hoeh, W., Lutz, R., Vrijenhoek, R., 1994. DNA primers for amplification of mitochondrial cytochrome c oxidase subunit I from diverse metazoan invertebrates. Mol. Mar. Biol. Biotechnol. 3, 294-299.

Funk, D.J., Omland, K.E., 2003. Species-level paraphyly and polyphyly: frequency, causes, and consequences, with insights from animal mitochondrial DNA. Annu. Rev. Ecol. Syst. 34, 397-423.

Grant, W.S., Cherry, M.I., 1985. Mytilus galloprovincialis Lmk. In Southern Africa. J. Exp. Mar. Biol. Ecol. 90, 179-191.

Guindon, S., Gascuel, O., 2003. A simple, fast, and accurate algorithm to estimate large phylogenies by maximum likelihood. Syst. Biol. 52, 696-704.

Hall, T.A., 1999. BioEdit: a user-friendly biological sequence alignment editor and analysis program for Windows95/98/NT. Nucleic Acids Symp. Ser. 41, 95-98.

Hey, J., 2001a. Genes, Categories and Species: The Evolutionary and Cognitive Causes of the Species Problem. Oxford University Press, New York.

Hey, J., 2001b. The mind of the species problem. Trends Ecol. Evol. 16, 326-329.

Hilbish, T.J., Mullinax, A., Dolven, S.I., Meyer, A., Koehn, R.K., Rawson, P.D. 2000. Origin of the antitropical distribution pattern in the marine mussel (Mytilus spp.): routes and timing of transequatorial migration. Mar. Biol 136, 69-77.

Hollyday, N.P., Read, J.F., 1998. Surface oceanic fronts between Africa and Antarctica. Deep Sea Res. I. 45, 217-238.

Koehn, R.K., 1991. The genetics and taxonomy of species in the genus Mytilus. Aquaculture 94, 125-145.

Kruskal, J.B., Wish, M., 1978. Multidimensional Scaling. Sage Publications, Beverly Hills.

Kumar, S., Tamura, K., Nei, M., 2004. MEGA 3: integrated software for molecular evolutionary genetics analysis and sequence alignment. Brief. Bioinform. 5 , 150-163.

Lee, S.Y., Morton, B., 1985. The introduction of the Mediterranean mussel Mytilus galloprovincialis into Hong Kong. Malac. Rev. 18, 107-109.

Mc Donald, J.H., Koehn, R.K., 1988. The mussels Mytilus galloprovincialis and M. trossulus on the Pacific coast of North America. Mar. Biol. 99, 111-118.

McDonald, J.H., Seed, R., Koehn, R.K., 1991. Allozymes and morphometric characters of three species of Mytilus in the Northern and Southern Hemispheres. Mar. Biol. $111,323-333$.

Mizi, A., Zouros, E., Moschonas, N., Rodakis, G.C., 2005. The complete maternal and paternal mitochondrial genomes of the Mediterranean mussel Mytilus galloprovincialis: implications for the doubly uniparental inheritance mode of mtDNA. Mol. Biol. Evol. 22, 952-967.

Mueller, R.L., 2006. Evolutionary rates, divergence dates, and the performance of mitochondrial genes in bayesian phylogenetic analysis. Syst. Biol. 55, 289-300.

Nei, M., 1987. Molecular Evolutionary Genetics. Columbia University Press, New York.

Nei, M., Li, W.-H., 1979. Mathematical model for studying genetic variation in terms of restriction endonucleases. Proc. Natl. Acad. Sci. USA 76, 5269-5273.

Nichols, R., 2001. Gene trees and species trees are not the same. Trends Ecol. Evol. $16,358-364$.

Nilsson, C.S., Cresswell, G.R., 1981. The formation and evolution of Eastern Australian Current eddies. Progr. Oceanogr. 9, 133-183.

Nylander, J.A.A., 2004. MrAIC.pl. Program distributed by the author, Evolutionary Biology Centre, Uppsala University.
Palumbi, S.R., Martin, A.P., Romano, S., McMillan, W.O., Stice, L., Grabowski, G., 1991. The Simple Fool's Guide to PCR. Version 2.0. Department of Zoology, University of Hawaii, Honolulu.

Quesada, H., Gallagher, C., Skibinski, D.A.G., Skibinski, D.O.F., 1998a. Patterns of polymorphism and gene flow of gender-associated mitochondrial DNA lineages in European mussel populations. Mol. Ecol. 7, 1041-1051.

Quesada, H., Stuckas, H., Skibinski, D.O.F., 2003. Heteroplasmy suggests paternal cotransmission of multiples genomes and pervasive reversion of maternally into paternally transmitted genomes of mussels (Mytilus) mitochondrial DNA. J. Mol. Evol. 57, S138-S147.

Quesada, H., Warren, M., Skibinski, D.O.F., 1998b. Nonneutral evolution and differential mutation rate of gender-associated mitochondrial DNA lineages in the Marine mussels Mytilus. Genetics 149, 1511-1526.

Quesada, H., Wenne, R., Skibinski, D.O.F., 1995. Differential introgression of mitochondrial DNA across species boundaries within the marine mussel genus Mytilus. Proc. Roy. Soc. B-Biol. Sci. 262, 51-56.

Rawson, P.D., 2005. Nonhomologous recombination between the large unassigned region of the male and female mitochondrial genomes in the mussel, Mytilus trossulus. J. Mol. Evol. 61, 717-732.

Rawson, P.D., Hilbish, T.J., 1995. Evolutionary relationships among the male and female mitochondrial DNA lineages in the Mytilus edulis species complex. Mol. Biol. Evol. 12, 893-901.

Rawson, P.D., Hilbish, T.J., 1998. Asymmetric introgression of mitochondrial DNA among European populations of blue mussels (Mytilus spp.). Evolution 52, 100108.

Riginos, C., Hickerson, M.J., Henzler, C.M. Cunningham, C.W., 2004. Differential patterns of male and female mtDNA exchange across the Atlantic Ocean in the blue mussel, Mytilus edulis. Evolution 58, 2438-2451.

Rozas, J., Sanchez-DelBarrio, J.C., Messeguer, X., 2003. DnaSP, DNA polymorphism analysis by the coalescent and other methods. Bioinformatics 19, 2496-2497.

Sang, T., Zong, Y., 2000. Testing hybridization hypotheses based on incongruent gene trees. Syst. Biol. 49, 422-434.

Skibinski, D.O.F., Beardmore, J.A., Cross, T.F., 1983. Aspects of the population genetics of Mytilus (Mytilidae; mollusca) in the British Isles. Biol. J. Linn. Soc. 19, 137-183.

Tajima, F., 1993. Simple methods for testing molecular clock hypothesis. Genetics 135, 599-607.

Tamura, K., Nei, N., 1993. Estimation of the number of nucleotide substitution in the control region of mitochondrial DNA in Humans and Chimpanzees. Mol. Biol. Evol. 10, 512-526.

Thompson, J.D., Higgins, D.J., Gibson, T.J., 1994. ClustalW: improving the sensitivity of progressive multiple alignment through sequence weighting, positions-specific gap penalties and weight matrix choice. Nucleic Acids Res. 22, 4673-4680.

Vermeij, G.J., 1992. Trans-equatorial connections between biotas in the temperate eastern Atlantic. Mar. Biol. 112, 343-348.

Walsh, P.S., Metzger, D.A., Higushi, R., 1991. Chelex 100 as a medium for simple extraction of DNA for PCR-based typing from forensic material. BioTechniques 10, 506-513.

Wares, J.P., Cunningham, C.W., 2001. Phylogeography and historical ecology of the North Atlantic interdidal. Evolution 55, 2455-2469.

Watterson, G.A., 1975. On the number of segregating sites in genetic models without recombination. Theor. Popul. Biol. 7, 256-276.

Wilkins, N.P., Fujino, K., Gosling, E.M., 1983. The Mediterranean mussel Mytilus galloprovincialis Lmk. Biol. J. Linn. Soc. 20, 365-374 (in Japan).

Wright, S., 1965. The interpretation of population structure by F-statistics with special regard to systems of mating. Evolution 19, 395-420. 